\title{
High-Tech Elements in Minerals of Massive Sulfide Deposits: LA-ICP-MS Data
}

\author{
V. Maslennikov $^{1(\bowtie)}$, S. Maslennikova ${ }^{1}$, N. Aupova ${ }^{1}$, A. Tseluyko $^{1}$, \\ R. Large ${ }^{2}$, L. Danyushevsky ${ }^{2}$, and U. Yatimov ${ }^{1}$ \\ ${ }^{1}$ Institute of Mineralogy, Ural Branch of RAS, Miass, Russia \\ mas@mineralogy.ru \\ ${ }^{2}$ CODES ARC Centre of Excellence in Ore Deposits, University of Tasmania, \\ Hobart, Australia
}

\begin{abstract}
LA-ICP-MS data on trace element zonation reflecting a local variation of physicochemical conditions of mineralization in black, grey and clear smokers from the Pacific and Atlantic oceans are used for comparison with the ancient chimneys of the Urals, Rudniy Altai, Pontides and Hokuroko massive sulfide deposits. Host rocks also influence on high-tech trace element assemblages in chalcopyrite: ultramafic (high $\mathrm{Se}, \mathrm{Sn}, \mathrm{Co}, \mathrm{Ni}, \mathrm{Ag}$ and $\mathrm{Au}) \rightarrow$ mafic (high $\mathrm{Co}, \mathrm{Se}$, Mo and low $\mathrm{Bi}, \mathrm{Au}$ and $\mathrm{Pb}$ ) $\rightarrow$ bimodal mafic (high $\mathrm{Te}, \mathrm{Au}, \mathrm{Ag}$, $\mathrm{Bi}, \mathrm{Pb}, \mathrm{Co}$, moderate $\mathrm{Se}$, and variable $\mathrm{As}$ and $\mathrm{Sb}$ ) $\rightarrow$ bimodal felsic (high As, $\mathrm{Sb}, \mathrm{Mo}, \mathrm{Pb}$, moderate $\mathrm{Bi}$, and low $\mathrm{Co}$, Te and $\mathrm{Se}$ ). In sphalerite of the same range, the contents of $\mathrm{Bi}, \mathrm{Ga}, \mathrm{Pb}, \mathrm{In}, \mathrm{Ag}, \mathrm{Au}$ and $\mathrm{Sb}$ increase versus $\mathrm{Fe}, \mathrm{Se}, \mathrm{Sn}$ and Co. The variations in pyrite coincide with these changes. Diagenetic evolution of high-tech elements is recognized in sulfide nodules.
\end{abstract}

Keywords: LAICP-MS · Trace elements · Chimneys ·

Massive sulfide deposits

\section{Introduction}

The bulk minor and trace element analyses indicate significant influence of host rocks on the metal inventory of the modern and ancient massive sulfide deposits. However, these general data can't provide dramatic improvement of the extraction of high-tech elements from massive sulphide ores. In contrast, the results of the quantitative laser ablation inductively coupled plasma mass spectrometry (LA-ICP-MS) show concentration of most trace metals in pyrite, chalcopyrite and sphalerite varieties as a function of physicochemical parameters of the fluid as well as host rock composition. Local LA-ICP-MS analyses of the sulphides provides a new insight into the processes of ore treatment and recovery of high-tech elements. The chimney fragments, sulfide turbidites, and their ore diagenites are suitable subject of this style of the research. The study is a key basement for fither improvement of mining and metallurgical processes. 


\section{Methods and Approaches}

In this paper, we use new LA-ICP-MS data on minor and trace elements in sulfides from Rudniy Altai, Pontides and Hokuroko massive sulfide deposits. Original LA-ICPMS data on smokers from the Pacific and Atlantic oceans are used for comparison with the ancient chimney material. The sulfide nodules are the other important subject of the research reflecting chemical evolution of diagenetic and metamorphic processes.

Quantitative LA-ICP-MS analysis of sulfides from chimneys for a wide range of major and trace elements (Fe, Cu, Zn, Co, Ni, Au, Ag, Bi, Pb, Tl, Cd, As, Te, Se, Mo, $\mathrm{Sn}, \mathrm{V}, \mathrm{Ti}$ and $\mathrm{Mn}$ ) was carried out using a New Wave $213 \mathrm{~nm}$ solid-state laser microprobes coupled to an Agilent 4500 quadrupole ICP-MS housed at the CODES LA-ICP-MS analytical facility, University of Tasmania and Institute of Mineralogy UB RAS. For this study, quantitative analyses were performed by ablating spots ranging in diameter from 40 to 60 microns. Data reduction was undertaken according to standard methods (Danyushevsky et al. 2011). The LA-ICP-MS was also used for detection of rare mineral microinclusions in the sulfides studied and for analysis of trace elements in telluride phases. Each zone of the chimney and nodules are characterized by LA-ICPMS-images (Large et al. 2009).

\section{Results and Discussion}

A variety of very well preserved modern black, grey, white and clear smokers (Pacific and Atlantic oceans) and fossil vent chimneys from the Urals, Rudniy Altai, Pontides and Hokuroko massive sulfide deposit show systematic trace element distribution patterns across chimneys. Chalcopyrite is enriched in $\mathrm{Se}, \mathrm{Sn}, \mathrm{Bi}, \mathrm{Co}, \mathrm{Mo}$, and Te. Sphalerite in the conduits and the outer chimney wall contains elevated $\mathrm{Sb}, \mathrm{As}, \mathrm{Pb}, \mathrm{Co}$, $\mathrm{Mn}, \mathrm{U}$, and V. He highest concentrations of most trace elements are found in colloform pyrite within the outer wall of the chimneys, and likely result from rapid precipitation in high temperature-gradient conditions. The trace element concentration in the outer wall colloform pyrite decrease in the following order, from the outer wall inwards; $\mathrm{Tl}>\mathrm{Ag}>\mathrm{Ni}>\mathrm{Mn}>\mathrm{Co}>\mathrm{As}>\mathrm{Mo}>\mathrm{Pb}>\mathrm{Ba}>\mathrm{V}>\mathrm{Te}>\mathrm{Sb}>\mathrm{U}>\mathrm{Au}>\mathrm{Se}>$

$\mathrm{Sn}>\mathrm{Bi}$, governed by the strong temperature gradient. In contrast, pyrite in the high- to mid-temperature central conduits exhibit concentration of $\mathrm{Se}, \mathrm{Sn}, \mathrm{Bi}, \mathrm{Te}$, and $\mathrm{Au}$. The zone between the inner conduit and outer wall is characterised by recrystallization of colloform pyrite to euhedral pyrite, which becomes depleted in all trace elements except Co, As and Se. The mineralogical and trace element variations between chimneys are likely due to increasing $\mathrm{fO}_{2}$ and decreasing temperature caused by mixing of hydrothermal fluids with cold oxygenated seawater (Maslennikov et al. 2009).

Host rocks also influence on high-tech trace element assemblages in chalcopyrite: ultramafic (high $\mathrm{Se}, \mathrm{Sn}, \mathrm{Co}, \mathrm{Ni}, \mathrm{Ag}$ and $\mathrm{Au}$ ) $\rightarrow$ mafic (high $\mathrm{Co}, \mathrm{Se}, \mathrm{Mo}$ and low $\mathrm{Bi}, \mathrm{Au}$ and $\mathrm{Pb}$ ) $\rightarrow$ bimodal mafic (high $\mathrm{Te}, \mathrm{Au}, \mathrm{Ag}, \mathrm{Bi}, \mathrm{Pb}, \mathrm{Co}$, moderate $\mathrm{Se}$, and variable $\mathrm{As}$ and $\mathrm{Sb}$ ) $\rightarrow$ bimodal felsic (high $\mathrm{As}, \mathrm{Sb}, \mathrm{Mo}, \mathrm{Pb}$, moderate $\mathrm{Bi}$, and low $\mathrm{Co}$, Te and $\mathrm{Se}$ ). In sphalerite of the same range, the contents of $\mathrm{Bi}, \mathrm{Ga}, \mathrm{Pb}, \mathrm{In}, \mathrm{Ag}, \mathrm{Au}$ and $\mathrm{Sb}$ increase versus $\mathrm{Fe}, \mathrm{Se}, \mathrm{Sn}$ and $\mathrm{Co}$. The variations in pyrite coincide with these changes (Maslennikov et al. 2017). 
The next stage of mineral and chemical differentiation is halmyrolysis of clastic sulfide sediments followed by diagenesis, anadiagenesis and metamorphism. Halmyrolysis as a leaching process of clastic sulfide sediments give way to redeposition of high-tech element such as $\mathrm{Se}, \mathrm{Te}, \mathrm{Au}, \mathrm{Ag}, \mathrm{Sn}$, and In as own minerals in enrichment submarine supergene zones. The inclusions of authigenic mineral such as $\mathrm{Pb}, \mathrm{Ag}, \mathrm{Au}-$ tellurides, $\mathrm{Ag}$ and $\mathrm{Pb}$-selenides, $\mathrm{In}, \mathrm{Cu}, \mathrm{Ag}, \mathrm{Sn}, \mathrm{Ge}$-sulfides, and $\mathrm{Sn}$-oxide are increased in sizes in the enrichment submarine supergene zones of massive sulfide deposits.

In many massive sulfide deposits, sulphide nodules have a zonal structure: the nucleus of the poikilite pyrite (zone A) is successively surrounded by the fringes of metacrystalline pyrite (zone B) and marcasite (zone C). Each zone is characterized by own mineralogical features, which are reflected in the results of LA-ICP-MS-images ("microtopochemistry") of the surface of the nodule cut. It is assumed that at the first stage, the source of the substance for nodule growth was the products of the halmyrolysis of hyaloclastites containing an admixture of sulphide material. In the diagenetic nucleus of nodule, the chemical elements typical of illite $(\mathrm{Si}, \mathrm{Al}, \mathrm{K}, \mathrm{Mg}, \mathrm{V}, \mathrm{Cr}$,), rutile $(\mathrm{Ti}, \mathrm{W})$, apatite $(\mathrm{Ca}, \mathrm{Mn}, \mathrm{U})$, galena $(\mathrm{Pb}, \mathrm{Bi}, \mathrm{Sb}, \mathrm{Ag})$, bismuth sulphosalts $(\mathrm{Bi}, \mathrm{Cu}, \mathrm{Pb})$, bornite $(\mathrm{Cu}, \mathrm{Bi}, \mathrm{Ag})$, tetrahedrite-tennantite $(\mathrm{Cu}, \mathrm{As}, \mathrm{Sb})$, chalcopyrite ( $\mathrm{Se}, \mathrm{Te}, \mathrm{Cu})$, native gold $(\mathrm{Au}, \mathrm{Ag}, \mathrm{Hg})$ and barite poikilites. In the pyrite, the high contents of $\mathrm{Co}$ and $\mathrm{Ni}$ are suggested to be substituted for $\mathrm{Fe}^{2+}$. Only signs of tellurides of bismuth are guessed. Zone B, probably formed in the early anadiagenetic stage, is depleted of most trace elements, with the exception of $\mathrm{Cu}, \mathrm{Pb}$, and $\mathrm{Ag}$. Formation of latest zone $\mathrm{C}$ was accompanied by of $\mathrm{Cd}$, In, Tl, As, Sb, Mo, and Ni saturation.

\section{Conclusions}

The mineralogical and trace element variations between chimneys are likely due to increasing of $\mathrm{O}_{2}$ and decreasing temperature caused by mixing of hydrothermal fluids with cold oxygenated seawater. The next stage of trace element differentiation is halmyrolysis of sulfide sediments followed by diagenesis, anadiagenesis and metamorphism. Halmyrolysis as a leaching process of clastic sulfide sediments gives a way to redeposition of high-tech element such as $\mathrm{Se}, \mathrm{Te}, \mathrm{Au}, \mathrm{Ag}, \mathrm{Sn}$, and $\mathrm{In}$ as own minerals in enrichment submarine supergene zones. The enrichment in the core of sulfide nodules is changed to trace element depletion in later epigenetic stages.

Local LA-ICP-MS analyses of the sulphides provides new insight into the processes of selective ore treatment and recovery of high-tech elements from different genetic ore varieties in implication to diverse ore formational types of massive sulfide deposits.

Aknowledgements. LA-ICP-MS analyses were carried out during visiting programs (2005, 2009, 2012, 2013, 2015) sponsored by the ARC Centre of Excellence grant to CODES. The research of sulphide nodules was supported by the Russian Foundation for Basic Research (project no. 17-05-00854) in the Institute of Mineralogy UB RAS. 


\section{References}

Danyushevsky LV, Robinson R, Gilbert S, Norman M, Large R, McGoldrick P, Shelley JMG (2011) Routine quantitative multi-element analysis of sulfide minerals by laser ablation ICPMS: standard development and consideration of matrix effects. Geochim Explor Environ Anal 11:51-60

Large RR, Danyushevsky L, Hillit H, Maslennikov V, Meffere S, Gilbert S, Bull S, Scott R, Emsbo P, Thomas H, Singh B, Foster J (2009) Gold and trace element zonation in pyrite using a laser imaging technique: implications for the timing of gold in orogenic and Carlinstyle sediment-hosted deposits. Econ Geol 104:635-668

Maslennikov VV, Maslennikova SP, Large RR, Danyushevsky LV (2009) Study of trace element zonation in vent chimneys from the Silurian Yaman-Kasy VHMS (the Southern Urals, Russia) using laser ablation inductively coupled plasma mass spectrometry (LA-ICP MS). Econ Geol 104:1111-1141

Maslennikov VV, Maslennikova SP, Ayupova NR, Zaykov VV, Tseluyko AS, Melekestseva IY, Large RR, Danyushevsky LV, Herrington RJ, Lein AT, Tessalina SG (2017) Chimneys in Paleozoic massive sulfide mounds of the Urals VMS deposits: mineral and trace element comparison with modern black, grey, white and clear smokers. Ore Geol Rev 85:64-106

Open Access This chapter is licensed under the terms of the Creative Commons Attribution 4.0 International License (http://creativecommons.org/licenses/by/4.0/), which permits use, sharing, adaptation, distribution and reproduction in any medium or format, as long as you give appropriate credit to the original author(s) and the source, provide a link to the Creative Commons license and indicate if changes were made.

The images or other third party material in this chapter are included in the chapter's Creative Commons license, unless indicated otherwise in a credit line to the material. If material is not included in the chapter's Creative Commons license and your intended use is not permitted by statutory regulation or exceeds the permitted use, you will need to obtain permission directly from the copyright holder.

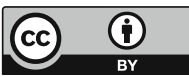

